\title{
BANTUAN HUKUM TIMBAL BALIK DALAM TINDAK PIDANA NARKOTIKA Oleh:
}

Ni Luh Gede Yogi Arthani' ; Made Emy Andayani Citra ${ }^{2}$

E-mail : yogi_arthani@yahoo.com ${ }^{1}$; emyandayanifh@gmail.com²

Dosen Fakultas Hukum Universitas Mahasaraswati Denpasar

\begin{abstract}
Ilicit Traffic in Narcotic Drugs is carried out by international networks operating in several countries. Ilicit traffic in narcotic drugs results in huge financial and wealth gains that enable transnational crime organizations to penetrate, pollute and undermine the structure of government, legitimate commercial and financial business, and society at all levels. In dealing with this situation, Indonesia harmonizes the law through mutual legal assistance arrangements. In this study two issues will be discussed namely legal reform through mutual legal assistance and mutual legal assistance in narcotics crimes.

Legal reform is a policy carried out by a country to deal with the situation that occurs in the country. The development of transnational crime was responded by the state through a policy of mutual legal assistance as outlined in the Law of the Republic of Indonesia Number 1 of 2006 concerning Reciprocal Assistance in Criminal Matters. Cooperation between countries in the process of law enforcement needs to be done to tackle the crime of trafficking in narcotics. llicit traffic in narcotic drugs is carried out by involving several countries. Reciprocal legal assistance in narcotics crimes can be implemented in three ways, namely diplomatic channels, through central authorities and through direct cooperation between law enforcement agencies.
\end{abstract}

Keywords: Mutual legal assistance, llicit Traffic, Narcotic Drugs

\section{Abstrak}

Perdagangan llegal Narkotika dilakukan oleh jaringan internasional yang beroperasi di beberapa negara. Perdagangan ilegal obat-obatan narkotika menghasilkan keuntungan finansial dan kekayaan yang besar yang memungkinkan organisasi kejahatan transnasional menembus, mencemari dan merusak struktur pemerintahan, bisnis komersial dan finansial yang sah, dan masyarakat di semua tingkatan. Dalam menghadapi situasi ini, Indonesia melakukan harmonisasi hukum melalui pengaturan bantuan hukum timbal balik. Dalam kajian ini akan dibahas dua hal yaitu reformasi hukum melalui bantuan hukum timbal balik dan bantuan hukum timbal balik dalam tindak pidana narkotika.

Reformasi hukum merupakan suatu kebijakan yang dilakukan oleh suatu negara untuk menghadapi keadaan yang terjadi di negaranya. Perkembangan kejahatan transnasional direspon oleh negara melalui kebijakan bantuan hukum timbal balik yang tertuang dalam Undang-Undang Republik Indonesia Nomor 1 Tahun 2006 tentang Bantuan Timbal Balik dalam Masalah Pidana. Kerja sama antar negara dalam proses penegakan hukum perlu dilakukan untuk menanggulangi tindak pidana perdagangan narkotika. Peredaran gelap narkotika dilakukan dengan melibatkan beberapa negara. Bantuan hukum timbal balik dalam tindak pidana narkotika dapat dilakukan dengan tiga cara yaitu jalur diplomatik, melalui otoritas pusat dan melalui kerjasama langsung antar lembaga penegak hukum.

Kata Kunci: Bantuan hukum timbal balik, Peredaran Gelap, Narkotika 


\section{PENDAHULUAN}

Narkotika merupakan zat yang sangat penting dalam terapi pengobatan, namun dapat menimbulkan akibat fatal apabila dikonsumsi tanpa petunjuk dokter dalam dosis yang sesuai. Dalam Pasal 7 Undang-undang Nomor 35 Tahun 2009 secara tegas menyatakan "Narkotika hanya dapat digunakan untuk kepentingan pelayanan kesehatan dan/atau pengembangan ilmu pengetahuan dan teknologi." Narkotika adalah obat yang dapat menghilangkan (terutama) rasa nyeri yang berasal dari daerah visceral dan dapat menimbulkan efek stupor (bengong, masih sadar namun harus digertak) serta adiksi. . Wijaya A.W. 1985 Menurut Soedjono, narkotika merupakan sejenis zat yang bila digunakan (dimasukkan ke dalam tubuh) akan membawa pengaruh terhadap si pemakai. Pengaruh tersebut berupa menenangkan, merangsang dan menimbulkan khayalan (halusinasi).

Penyalahgunaan narkotika juga berakibat fatal terhadap kesehatan penggunanya.

Pentingnya peredaran narkotika diawasi secara ketat karena saat ini pemanfaatannya banyak untuk hal-hal yang negatif. Di samping itu, melalui perkembangan teknologi informasi dan komunikasi, penyebaran narkotika sudah menjangkau hampir ke semua wilayah di Indonesia hingga ke pelosok-pelosok. Daerah yang sebelumya tidak pernah tersentuh oleh peredaran narkotika lambat laun berubah menjadi sentra peredaran narkotika. Begitu pula, anak-anak yang pada mulanya awam terhadap barang haram ini telah berubah menjadi sosok pecandu yang sukar untuk dilepaskan ketergantungannya.

Penyalahgunaan

narkotika menjadi permasalahan hukum yang terjadi di berbagai belahan dunia. Peningkatan jumlah penyalahgunaan narkotika tentunya menurunkan kualitas kesehatan para pecandu. Perilaku yang dilakukan para pengguna narkotika cenderung ke arah perilaku berisiko seperti kebiasaan merokok yang terusmenerus, konsumsi alkohol, dan hubungan seksual yang tidak aman, merokok.

Peredaran gelap narkotika dilakukan secara lintas batas negara. Jaringan kejahatan transnasional memang bukan persoalan baru, operasi-operasi kejahatan lintas batas negara telah berlangsung sejak lama. Tetapi baru dalam dua dekade terakhir ini bentuk-bentuk kejahatan transnasional menunjukkan pengingkatan kegiatan, lebih terorganisir rapi dan bergerak secara lebih efektif serta dapat melaksanakan operasi-operasi kejahatannya tanpa mendapat hambatan hukum yang cukup berarti.

Secara faktual, kasus penyalahgunaan narkoba menjadi kejahatan transnasional terbanyak yang ditangani Kepolisian Republik Indonesia sepanjang 2019. Jumlahnya mencapai 30.884 kasus atau 85,2 persen dari total kejahatan transnasional yang ada. Dalam catatan akhir tahun Mabes Polri dapat dilihat bahwa secara keseluruhan jumlah kejahatan transnasional jumlahnya mencapai 36.219 kasus. Angka tersebut menurun 19,5 persen dibanding 2018 yang tercatat ada 45.048 kasus. Pada 2019 mengalami penurunan 8.829 kasus. Kejahatan transnasional yang dominan pada 2019 adalah penyalahgunaan narkoba.

Sinergitas dalam pemberantasan peredaran gelap narkotika antara Badan Narkotika Nasional (BNN) dengan Bea dan Cukai kembali membuahkan hasil. Sebanyak 28.240 gram shabu dan 21.727 butir ekstasi dari 2 (dua) kasus berbeda yang diduga diselundupkan dari Malaysia ke 
Indonesia melalui jalur tikus di perbatasan Entikong, berhasil diungkap dengan meringkus 4 (empat) orang tersangka.Pengungkapan kasus ini berawal dari adanya informasi masyarakat yang diteruskan dengan analisa dan penyelidikan intelijen, hingga akhirnya diketahui bahwa akan adanya pengiriman narkotika dari Kuching, Malaysia, ke Indonesia melalui perbatasan Entikong, Sanggau, Kalimantan Barat. Kasus pertama diungkap petugas pada Senin (26/3), di Jl. Raya Sosok Tayan Kab. Sanggau, Kalimantan Barat. Dua orang pria berinisial Su alias Yo (43) dan An alias Ab (54) diamankan petugas pada saat melintas Kawasan Sosok Tayan tersebut. Hasil pemeriksaan yang dilakukan terhadap mobil yang dikendarai pelaku, ditemukan $7 \mathrm{Kg}$ shabu dan 21.727 butir ekstasi.

Peredaran narkotika lintas batas negara perlu ditanggulangi oleh masyarakat global melalui kerjasama antar negara. Dalam konteks pembangunan hukum menuju kondisi yang lebih baik, dapat dirumuskan paling tidak dua hal. Pertama bagaimana faktor domestik, baik pemerintah maupun masyarakat memainkan peranannya dalam pembangunan tata aturan. Hal ini tentu sangat dipengaruhi oleh ideologi politik hukum atau untuk mudahnya politik pembangunan hukum. Kedua bagaimana kondisi hukum ke depan dapat menjawab perkembangan global dan regional yang berpengaruh pada paradigma negara dalam menjalankan pembangunan dan pembaruan hukum. Salah satu bentuk kerjasama antar negara dalam pemberantasan peredaran gelap narkotika adalah melalui bantuan timbal balik atau Mutual Legal Assistance.

I Made Wirya Darma et.al. mengatakan "Mutual Legal Assistance (MLA) is basically a form of mutual agreement in criminal matters. The establishment of Mutual Legal Assistance is motivated by the factual conditions that as a result of differences in the criminal legal system between several countries resulting in inaction in the investigation of crime. (Terjemahan bebas: Mutual Legal Assistance pada dasarnya merupakan bentuk kesepakatan bersama dalam masalah pidana. Pembentukan Mutual Legal Assistance dilatarbelakangi oleh kondisi faktual yang sebagai akibat adanya perbedaan sistem hukum pidana antar beberapa negara yang mengakibatkan tidak adanya tindakan dalam penyidikan tindak pidana). Kejahatan narkotika merupakan kejahatan yang terorganisir, oleh sebab itu kerjasama antara penegak hukum saja tidak cukup, melainkan diperlukan kerjasama yang lebih besar.

Mutual Legal Assistance muncul sebagai salah satu upaya dalam mengatasi dan memberantas berbagai kejahatan yang sifatnya lintas batas (transnasional) Manfaat kerjasama timbal balik dalam masalah pidana untuk menyelesaikan perkara-perkara pidana di Indonesia, yaitu untuk memberikan dasar hukum yang kuat mengenai kerjasama antarnegara dalam bentuk bantuan timbal balik dalam masalah pidana dan sebagai sarana untuk mendukung dan menjamin kepastian, ketertiban, dan perlindungan hukum yang berintikan keadilan dan kebenaran. Tindak pidana terutama yang bersifat transnasional atau lintas negara dapat mengakibatkan timbulnya permasalahan hukum suatu negara dengan negara lain yang memerlukan penanganan melalui hubungan balik berdasarkan hukum di masing-masing negara. Oleh karena itu penanganan tindak pidana transnasional harus dilakukan dengan bekerjasama antarnegara dalam bentuk bantuan timbal balik dalam masalah pidana. 


\section{METODE}

Penelitian ini dilakukan dengan menggunakan metode penelitian emperis dengan sifat penelitian deskriptif kualitatif, dengan sumber data yang terdiri dari sumber data primer, sumber data sekunder, menggunakan teknik pengumpulan data dengan menggunakan wawancara, dan untuk menganalisa data yang telah dikumpulkan maka dipergunakan beberapa teknik, yaitu teknik deskripsi, kualitatif.

\section{PEMBAHASAN}

\section{Pembaruan Hukum Melalui Bantuan Hukum Timbal Balik}

Pembaharuan hukum pidana yang menyeluruh itu harus meliputi pembaharuan hukum pidana material, hukum pidana formal dan hukum pelaksanaan pidana. Hukum melalui politik hukum pidana diarahkan pada social defence. Adapun aspek-aspek social defence (perlindungan masyarakat) meliputi:

Perlindungan terhadap perbuatan jahat (penanggulangan kejahatan).

Perlindungan terhadap orang jahat (perbaikan si pelaku)

Perlindungan terhadap penyalahgunaan sanksi/ reaksi (mengatur dan membatasi kesewenangan penguasa dan warga masyarakat).

Perlindungan

terhadap

keseimbangan kepentingan/ nilai yang terganggu (memelihara/ memulihkan keseimbangan masyarakat).

Pembaharuan hukum pidana yang menyeluruh itu harus meliputi pembaharuan hukum pidana material, hukum pidana formal dan hukum pelaksanaan pidana.

Indonesia

komitmen Politik politik adalah kebijakan dari negara melalui badan-badan negara yang berwenang untuk menetapkan peraturanperaturan yang dikehendak, yang diperkirakan akan digunakan untuk mengekspresikan apa yang terkandung dalam masyarakat dan untuk mencapai apa yang dicitacitakan. Salah satu bentuk politik hukum Indonesia dalam konteks kerjasama hukum dengan negara lain adalah dengan mengatur mengenai bantuan hukum timbal balik (mutual legal assistance).

Politik Hukum Indonesia dalam bantuan hukum timbal balik (mutual legal assistance) diformulasikan pada Undang-Undang Republik Indonesia Nomor 1 Tahun 2006 Tentang Bantuan Timbal Balik dalam Masalah Pidana. Undang-undang tentang bantuan timbal balik ini, dianggap sebagai komplementer terhadap undang-undang ekstradisi sebagai instrumen hukum dalam menghadapi kejahatan transnasional. Permintaan penyerahan pelaku kejahatan (ekstradisi) tidak serta merta merupakan pengembalian aset hasil kejahatan yang dibawa pelaku kejahatan yang bersangkutan.

Pengaturan bantuan hukum timbal balik tidak lepas dari fakta hukum mengenai perkembangan kejahatan lintas negara. Pentingnya bantuan hukum timbal balik ini dapat dilihat pada United Nations Convention against Transnational Organized Crime. Negara-negara di ASEAN memiliki Treaty on Mutual Legal Asssistance in Criminal Matters. Pada bagian konsideran Undang-Undang Republik Indonesia Nomor 1 Tahun 2006 Tentang Bantuan Timbal Balik dalam Masalah Pidana disebutkan bahwa tindak pidana terutama yang bersifat transnasional atau lintas negara mengakibatkan timbulnya permasalahan hukum suatu negara dengan negara lain yang memerlukan penanganan melalui hubungan baik berdasarkan hukum di masing-masing negara. Pada bagian berikutnya disebutkan bahwa penanganan tindak pidana transnasional harus dilakukan dengan bekerja sama antarnegara dalam bentuk bantuan timbal balik dalam masalah pidana, yang sampai saat ini belum ada landasan hukumnya. 
Kejahatan transnasional adalah kejahatan lintas negara (transnational crimes) dewasa ini dipandang sebagai salah satu ancaman serius terhadap keamanan global yang dituntut di bawah yurisdiksi hukum domestik/nasional, tidak berada di bawah yurisdiksi peradilan internasional karena salah satu unsur dari transnasional adalah adanya lintas batas negara, maka diperlukan kerjasama antar negara untuk membantu proses penegakan hukum. Adanya perjanjian mutlak diperlukan oleh negara-negara untuk dapat menuntut pelaku tindak pidana transnasional yang melewati lintas batas negara.

Tujuan dari terbentuknya Undang-Undang Republik Indonesia Nomor 1 Tahun 2006 Tentang Bantuan Timbal Balik dalam Masalah Pidana dapat dilihat dari ketentuan dalam Pasal 2 Undang-Undang Republik Indonesia Nomor 1 Tahun 2006 Tentang Bantuan Timbal Balik dalam Masalah Pidana yang menyatakan "Undang-Undang ini bertujuan memberikan dasar hukum bagi Pemerintah Republik Indonesia dalam meminta dan/atau memberikan bantuan timbal balik dalam masalah pidana dan pedoman dalam membuat perjanjian bantuan timbal balik dalam masalah pidana dengan negara asing." Tujuan dalam pembentukan Undang-Undang Republik Indonesia Nomor 1 Tahun 2006 Tentang Bantuan Timbal Balik dalam Masalah Pidana tidak dapat dilepaskan dari sejarah pembentukan mutual legal assistance sendiri. Sejarah pembentukan mutual legal assistance yang berawal dari kerjasama antar negara dalam suatu proses saling membantu dalam penyidikan masalah pidana yang bermula dari kerjasama antar kepolisian maupun "letters rogatory" yang merupakan suatu sistem permintaan bantuan yang didasarkan pada sikap saling menghargai dalam rangka mendapatkan alat bukti, yang selanjutnya berkembang menjadi suatu bentuk perjanjian dan berbagai bentuk bantuan lainnya.

Sifat transnasional dari kejahatan narkotika berimplikasi pada pentingnya bantuan hukum timbal balik dalam penanggulangan kejahatan ini. Peredaran gelap narkotika sebagai kejahatan transnasional dapat dilihat pada dasar menimbang Undangundang Nomor 35 Tahun 2009 tentang Narkotika yang menyatakan:

a.bahwa untuk mewujudkan masyarakat Indonesia yang sejahtera, adil dan makmur yang merata materiil dan spiritual berdasarkan Pancasila dan Undang-Undang Dasar Negara Republik Indonesia Tahun 1945, kualitas sumber daya manusia Indonesia sebagai salah satu modal pembangunan nasional perlu dipelihara dan ditingkatkan secara terus menerus, termasuk derajat kesehatannya;

b. bahwa untuk meningkatkan derajat kesehatan sumber daya manusia Indonesia dalam rangka mewujudkan kesejahteraan rakyat perlu dilakukan upaya peningkatan di bidang pengobatan dan pelayanan kesehatan, antara lain dengan mengusahakan ketersediaan Narkotika jenis tertentu yang sangat dibutuhkan sebagai obat serta melakukan pencegahan dan pemberantasan bahaya penyalahgunaan dan peredaran gelap Narkotika dan Prekursor Narkotika;

c.bahwa Narkotika di satu sisi merupakan obat atau bahan yang bermanfaat di bidang pengobatan atau pelayanan kesehatan dan pengembangan ilmu pengetahuan dan di sisi lain dapat pula menimbulkan ketergantungan yang sangat merugikan apabila disalahgunakan atau digunakan tanpa pengendalian dan pengawasan yang ketat dan saksama;

d.bahwa mengimpor, mengekspor, memproduksi, menanam, menyimpan, mengedarkan, dan/atau menggunakan Narkotika tanpa pengendalian dan pengawasan yang ketat dan seksama serta bertentangan dengan peraturan perundang-undangan merupakan 
tindak pidana Narkotika karena sangat merugikan dan merupakan bahaya yang sangat besar bagi kehidupan manusia, masyarakat, bangsa, dan negara serta ketahanan nasional Indonesia;

e.bahwa tindak pidana Narkotika telah bersifat transnasional yang dilakukan dengan menggunakan modus operandi yang tinggi, teknologi canggih, didukung oleh jaringan organisasi yang luas, dan sudah banyak menimbulkan korban, terutama di kalangan generasi muda bangsa yang sangat membahayakan kehidupan masyarakat, bangsa, dan negara sehingga Undang-Undang Nomor 22 Tahun 1997 tentang Narkotika sudah tidak sesuai lagi dengan perkembangan situasi dan kondisi yang berkembang untuk menanggulangi dan memberantas tindak pidana tersebut

Berdasarkan fungsi narkotika, maka pemerintah menggolongkan narkotika menjadi golongan I, golongan II dan golongan III sebagaimana yang diatur dalam Pasal 6 Undang-undang Nomor 35 Tahun 2009 yakni sebagai berikut:

Narkotika

sebagaimana dimaksud dalam Pasal 5 digolongkan ke dalam:

a. Narkotika Golongan I;

b. Narkotika Golongan II; dan

c. Narkotika Golongan III.

Penggolongan

Narkotika sebagaimana dimaksud pada ayat (1) untuk pertama kali ditetapkan sebagaimana tercantum dalam Lampiran I dan merupakan bagian yang tak terpisahkan dari UndangUndang ini.

Ketentuan mengenai perubahan penggolongan Narkotika sebagaimana dimaksud pada ayat (2) diatur dengan Peraturan Menteri.

Dalam Penjelasan Pasal 6 Undang-undang Nomor 35 Tahun 2009 dijabarkan bahwa "Narkotika Golongan I" adalah Narkotika yang hanya dapat digunakan untuk tujuan pengembangan ilmu pengetahuan dan tidak digunakan dalam terapi, serta mempunyai potensi sangat tinggi mengakibatkan ketergantungan. "Narkotika Golongan II" adalah Narkotika berkhasiat pengobatan digunakan sebagai pilihan terakhir dan dapat digunakan dalam terapi dan/atau untuk tujuan pengembangan ilmu pengetahuan serta mempunyai potensi tinggi mengakibatkan ketergantungan. "Narkotika Golongan III" adalah Narkotika berkhasiat pengobatan dan banyak digunakan dalam terapi dan/atau untuk tujuan pengembangan ilmu pengetahuan serta mempunyai potensi ringan mengakibatkan ketergantungan.

Narkotika Golongan I dilarang digunakan untuk kepentingan pelayanan kesehatan namun jumlah terbatas, Narkotika Golongan I dapat digunakan untuk kepentingan pengembangan ilmu pengetahuan dan teknologi dan untuk reagensia diagnostik, serta reagensia laboratorium setelah mendapatkan persetujuan Menteri atas rekomendasi Kepala Badan Pengawas Obat dan Makanan. Ruang lingkup Narkotika Golongan I meliputi:

Reagensia diagnostik adalah Narkotika Golongan I tersebut secara terbatas dipergunakan untuk mendeteksi suatu zat/bahan/benda yang digunakan oleh seseorang apakah termasuk jenis Narkotika atau bukan.

Reagensia laboratorium adalah Narkotika Golongan I tersebut secara terbatas dipergunakan untuk mendeteksi suatu zat/bahan/benda yang disita atau ditentukan oleh pihak Penyidik apakah termasuk jenis Narkotika atau bukan.

Narkotika Golongan II dan Golongan III yang berupa bahan baku, baik alami maupun sintetis, yang digunakan untuk produksi obat diatur dengan Peraturan Menteri. Walaupun narkotika Golongan I dan Golongan II dapat digunakan sebagai bahan baku obat, namun penggunaannya tetap diatur. Narkotika dalam bentuk obat jadi hanya dapat diedarkan setelah mendapatkan izin edar dari Menteri. 
Untuk mendapatkan izin edar dari Menteri, Narkotika dalam bentuk obat jadi harus melalui pendaftaran pada Badan Pengawas Obat dan Makanan. Jenis-jenis narkotika Golongan I, II dan III diatur dalam Lampiran UndangUndang Republik Indonesia Nomor 35 Tahun 2009 Tentang Narkotika dan perubahannya. Dengan demikian, apabila jenis narkotika tidak digunakan sesuai dengan keperluannya, maka perbuatan tersebut merupakan kejahatan narkotika.

Kejahatan lintas batas negara dalam peredaran gelap narkotika dilakukan secara terorganisir. Kejahatan terorganisasi adalah kejahatan yang dilakukan oleh suatu kelompok yang terstruktur yang terdiri atas 3 (tiga) orang atau lebih yang telah ada untuk suatu waktu tertentu dan bertindak bersama dengan tujuan melakukan suatu tindak pidana Narkotika. Berdasarkan kriminalisasi yang diatur dalam Undang-undang Nomor 35 Tahun 2009 tentang Narkotika, maka diatur beberapa perbuatan yang tergolong dan dapat memungkinkan terjadinya peredaran gelap narkotika. Adapun perbuatanperbuatan tersebut meliputi:

Menanam, memelihara, memiliki, menyimpan, menguasai, atau menyediakan Narkotika

Memiliki,

menguasai, atau

menyimpan,

Narkotika

Memproduksi,

mengekspor, atau

Narkotika

Menawarkan untuk dijual, menjual, membeli, menerima, menjadi perantara dalam jual beli, menukar, atau menyerahkan Narkotika.

Membawa,

mengangkut, atau mentransito

Narkotika

Peredaran gelap narkotika sebagai kejahatan transnational diakui pula oleh negara-negara di dunia yang dapat dilihat pada konsideran United Nations Convention Against llicit Traffic in Narcotic Drugs and Psychotropic Substances yang menyatakan "Aware that illicit traffic generates large financial profits and wealth enabling transnational criminal organizations to penetrate, contaminate and corrupt the structures of government, legitimate commercial and financial business, and society at all its levels." (Terjemahan: Sadar bahwa peredaran gelap menghasilkan keuntungan besar terhadap keuangan dan kekayaan yang memungkinkan organisasi kejahatan transnasional untuk menembus, mencemari dan merusak struktur pemerintahan, bisnis komersial dan keuangan yang sah, dan masyarakat disemua tingkatannya).

\section{Bantuan Hukum Timbal Balik dalam Kejahatan Narkotika}

Mutual legal assistance dapat dilihat dari perjanjian internasional. Dalam United Nations Convention Against Illicit Traffic in Narcotic Drugs and Psychotropic Substances disebutkan "The Parties shall consider, as may be necessary, the possibility of concluding bilateral or multilateral agreements or arrangements that would serve the purposes of, give practical effect to, or enhance the provisions of this article." (terjemahan: Para Pihak wajib mempertimbangkan, yang dianggap perlu, kemungkinan menyimpulkan perjanjian bilateral atau multilateral atau pengaturan yang akan melayani tujuan, memberikan efek praktis untuk, atau meningkatkan ketentuan pasal ini). Ketentuan mengenai "mutual legal assistance" diatur dalam Article 7 United Nations Convention Against Illicit Traffic in Narcotic Drugs and Psychotropic Substances, 1988. Dalam Pasal 7 disebutkan:

The Parties shall afford one another, pursuant to this article, the widest measure of mutual legal assistance in investigations, prosecutions and judicial proceedings in relation to criminal offences established in accordance with article 3, paragraph 1. Mutual legal assistance to be afforded in 
accordance with this article may be requested for any of the following purposes:

Taking evidence or statements from persons;

Effecting service of judicial documents;

Executing searches and seizures;

Examining objects and sites;

Providing information and evidentiary items;

Providing originals or certified copies of relevant documents and records, including bank, financial, corporate or business records;

Identifying or tracing proceeds, property, instrumentalities or other things for evidentiary purposes.

Terjemahan bebas:

Para Pihak harus saling, berdasarkan pasal ini, ukuran terluas bantuan hukum timbal balik dalam penyelidikan, penuntutan, dan pengadilan dalam kaitannya dengan tindak pidana yang ditetapkan sesuai dengan pasal 3 ayat 1 . Bantuan hukum timbal balik yang akan diberikan sesuai dengan artikel ini dapat diminta untuk tujuan-tujuan berikut:

Mengambil bukti atau pernyataan dari orang;

Mempengaruhi pelayanan dokumen pengadilan;

Pelaksana pencarian dan kejang;

Meneliti benda dan situs;

Memberikan informasi dan barang-barang bukti;

Memberikan asli atau salinan resmi dari dokumen yang relevan dan catatan, termasuk perbankan, keuangan, catatan perusahaan atau bisnis;

Mengidentifikasi atau melacak hasil, properti, sarana-sarana atau halhal lain untuk tujuan pembuktian.

Sebagai suatu negara yang saling terkoneksi dengan negara lain, maka Indonesia memiliki kebijakan dalam kerjasama internasional dalam penanggulangan kejahatan narkotika. Dalam Pasal 63 Undang-undang Republik Indonesia Nomor 35 Tahun 2009 tentang Narkotika dinyatakan
"Pemerintah mengupayakan kerjasama dengan negara lain dan/atau badan internasional secara bilateral dan multilateral, baik regional maupun internasional dalam rangka pembinaan dan pengawasan Narkotika dan Prekursor Narkotika sesuai dengan kepentingan nasional."

Dalam penjelasan Pasal 63 dinyatakan bahwa ketentuan ini menegaskan bahwa kerja sama internasional meliputi juga kerja sama dalam rangka pencegahan dan pemberantasan kejahatan Narkotika transnasional yang terorganisasi. Kerjasama internasional dalam penanggulangan kejahatan secara khusus diatur dalam Undang-Undang Republik Indonesia Nomor 1 Tahun 2006 Tentang Bantuan Timbal Balik dalam Masalah Pidana.

Ruang lingkup bantuan timbal balik dalam ketentuan tersebut dapat dilihat dari ketentuan Pasal 3 ayat (1) Undang-Undang Republik Indonesia Nomor 1 Tahun 2006 Tentang Bantuan Timbal Balik Dalam Masalah Pidana yang menyebutkan Bantuan timbal balik dalam masalah pidana, yang selanjutnya disebut Bantuan, merupakan permintaan Bantuan berkenaan dengan penyidikan, penuntutan, dan pemeriksaan di sidang pengadilan sesuai dengan ketentuan peraturan perundangundangan Negara Diminta. Dalam ayat (2) disebutkan Bantuan sebagaimana dimaksud pada ayat (1) dapat berupa: mengidentifikasi dan mencari orang;

mendapatkan pernyataan atau

bentuk lainnya; menunjukkan dokumen atau

bentuk lainnya; mengupayakan kehadiran orang untuk memberikan keterangan atau membantu penyidikan; menyampaikan surat; melaksanakan permintaan penggeledahan dan penyitaan; perampasan hasil tindak pidana; memperoleh kembali sanksi denda berupa uang sehubungan dengan tindak pidana; 
melarang transaksi kekayaan, membekukan aset yang dapat dilepaskan atau disita, atau yang mungkin diperlukan untuk memenuhi sanksi denda yang dikenakan, sehubungan dengan tindak pidana;

mencari kekayaan yang dapat dilepaskan, atau yang mungkin diperlukan untuk memenuhi sanksi denda yang dikenakan, sehubungan dengan tindak pidana; dan/atau

Bantuan lain yang sesuai dengan Undang-Undang ini.

Sebagai pelaksanaan dari ketentuan mengenai bantuan hukum timbal balik dalam masalah pidana maka Indonesia membuat berbagai perjanjian internasional mengenai hal tersebut. Indonesia memiliki beberapa perjanjian internasional mengenai Mutual Legal Assistance dalam masalah pidana yakni dengan Australia, China, Hong Kong, Republik Korea and 9 negara anggota ASEAN. Kerjasama internasional berakar dari penghargaan hak asasi manusia. Hal penting dalam negara hukum adalah adanya penghargaan dan komitmen menjunjung tinggi hak asasi manusia serta jaminan semua warga bersamaan kedudukannya di dalam hukum.

Kerja sama antarnegara diperlukan untuk mempermudah penanganan proses penyidikan, penuntutan, dan pemeriksaan di sidang pengadilan atas suatu masalah pidana yang timbul baik di Negara Peminta maupun Negara Diminta. Sebagaimana karakter hukum internasional, pelaksanaan bantuan hukum timbal balik juga menghargai dan menghormati kedaulatan negara. Asas atau prinsip bantuan timbal balik dalam masalah pidana dalam UndangUndang ini adalah didasarkan pada ketentuan hukum acara pidana, perjanjian antarnegara yang dibuat, dan konvensi dan kebiasaan internasional. Bantuan timbal balik dalam masalah pidana dapat dilakukan berdasarkan suatu perjanjian dan jika belum ada perjanjian maka bantuan dapat dilakukan atas dasar hubungan baik. Misalnya, meskipun Indonesia dan Amerika Serikat belum memiliki perjanjian bilateral Bantuan Timbal Balik dalam Masalah Pidana namun berdasarkan Undang-Undang bantuan timbal balik permintaan tersebut dapat dipenuhi dengan berdasarkan pada asas resiprositas dan hubungan baik.

Hak negara diminta untuk menolak permintaan bantuan yang bersifat tidak mutlak didasarkan pada prinsip resiprositas. Prinsip ini terutama sangat menentukan dalam menghadapi tindak pidana yang disebut tindak pidana yang dilakukan di luar wilayah negara peminta (extra territorial crime) dan tidak diatur menurut negara diminta atau terhadap tindak pidana yang diancam dengan pidana mati. Secara umum, pelaksanaan kerja sama dalam bantuan timbal balik pidana dapat dilaksanakan melalui tiga cara, yaitu jalur diplomatik, melalui otoritas pusat dan melalui kerja sama antar-lembaga penegakan hukum secara langsung.

Pengajuan permohonan melalui jalur diplomatik

Pengajuan permohonan melalui jalur ini, harus diajukan oleh aparat penegak hukum dari "Negara Peminta" pada otoritas diplomatik negara mereka. Permintaan ini kemudian akan diteruskan pada pihak diplomatik yang berwenang dari "Negara Diminta" yang kemudian akan meneruskan permintaan tersebut pada aparat penegak hukum "Negara Diminta" atau Kejaksaan untuk memenuhi permintaan tersebut. Kelemahan dari pengajuan permohonan melalui jalur ini adalah pelaksanaannya yang lambat sebab banyak tahapan yang harus dilalui sehingga waktu yang dibutuhkan untuk melaksanakan bantuan timbal balik pidana akan lebih banyak.

Pengajuan permohonan melalui otoritas pusat.

Proses yang lambat seperti yang terjadi dalam permohonan menggunakan jalur diplomatik. Selain itu, keberadaan otoritas pusat juga 
menjadi solusi untuk melakukan koordinasi dalam hal permintaan bantuan timbal balik pidana melibatkan lebih dari satu institusi penegakan hukum.

Disisi lain, keberadaan otoritas pusat juga dapat menjadi kelemahan dalam pelaksanaan bantuan timbal balik pidana. Kelemahan tersebut terjadi jika otoritas pusat kurang didukung oleh sumber daya yang memadai. Selain itu perbedaan penunjukan otoritas yang berwenang dalam pelaksanaan perjanjian internasional yang berbeda dapat menghambat kinerja kerja sama internasional melalui bantuan timbal balik pidana.

\section{Pengajuan permohonan langsung antar aparat penegak hukum}

Pengajuan permohonan melalui jalur ini dilakukan untuk meningkatkan efisiensi dalam bantuan timbal balik pidana. Bantuan timbal balik pidana yang dilakukan menggunakan mekanisme ini dapat dimanfaatkan dalam keadaan mendesak yang harus segera terjalin komunikasi antar-aparat penegak hukum seperti jaksa atau penyidik kepolisian dalam penegakan hukum pidana yang melibatkan lebih dari satu negara. Kerja sama dengan menggunakan mekanisme permohonan langsung antar lembaga penegak hukum bisa jadi merupakan mekanisme tercepat dalam pelaksanaan bantuan timbal balik pidana, tetapi dalam praktik penggunaan cara ini bukan tanpa kelemahan. Mekanisme ini kemungkinan akan sulit diajukan pada negara yang memiliki banyak jenis penegak hukum, karena "Negara Peminta" akan sulit menentukan pada pihak mana permohonan harus diajukan. Kelemahan lain dari mekanisme ini adalah aparat penegak hukum dan Jaksa pada "Negara Diminta" tidak cukup memahami tentang faktor yang mempengaruhi keputusan Pengajuan permohonan bantuan timbal balik pidana melalui jalur ini diajukan pada otoritas pusat yang ditunjuk untuk mewakili negara untuk mengajukan dan menerima dan menangani permohonan bantuan timbal balik pidana secara langsung. Otoritas pusat kemudian akan meneruskan permohonan pada institusi teknis yang kewenangannya paling sesuai dengan pemohonan yang diajukan. Melalui otoritas pusat, negara dapat memantau permintaan dan memastikan bahwa permintaan tersebut telah dilaksanakan. Pada umumnya negara menunjuk ministry of justice atau kejaksaan agung untuk menjadi otoritas pusat. Pengajuan dan penerimaan permintaan bantuan timbal balik oleh otoritas pusat dapat meningkatkan efektivitas kerja sama. Keberadaan otoritas pusat juga menghindari untuk bekerja sama, seperti hubungan politik antara yang "Negara Peminta" dan "Negara Diminta".

Sekurang-kurangnya ada 4 (empat) langkah yang harus dipenuhi untuk mengupayakan hukum atau aturan atau ketentuan dapat bekerja dan berfungsi (secara efektif), yaitu:

Adanya pejabat/aparat penegak hukum sebagai mana ditentukan dalam peraturan/ hukum tersebut.

Adanya

orang (individu/masyarakat) yang melakukan perbuatan hukum, baik yang mematuhi atau melanggar hukum.

Orang-orang

tersebut

mengetahui adanya peraturan.

Orang-orang tersebut sebagai subyek maupun obyek hukum bersedia untuk berbuat sesuai hukum.

Ketentuan dalam Pasal 6 Undang-Undang Republik Indonesia Nomor 1 Tahun 2006 Tentang Bantuan Timbal Balik dalam Masalah Pidana memungkinkan penolakan atas penolakan terhadap permintaan bantuan hukum yakni:

Permintaan Bantuan ditolak jika:

permintaan Bantuan berkaitan dengan suatu penyidikan, penuntutan, dan pemeriksaan di sidang pengadilan atau pemidanaan terhadap orang atas tindak pidana yang dianggap sebagai:

tindak pidana politik, kecuali pembunuhan atau percobaan 
pembunuhan terhadap kepala negara/kepala pemerintahan, terorisme; atau tindak pidana berdasarkan hukum militer;

Permintaan Bantuan berkaitan dengan suatu penyidikan, penuntutan, dan pemeriksaan di sidang pengadilan terhadap orang atas tindak pidana yang pelakunya telah dibebaskan, diberi grasi, atau telah selesai menjalani pemidanaan;

Permintaan Bantuan berkaitan dengan suatu penyidikan, penuntutan, dan pemeriksaan di sidang pengadilan atau pemidanaan terhadap orang atas tindak pidana yang jika dilakukan di Indonesia tidak dapat dituntut;

Permintaan Bantuan diajukan untuk menuntut atau mengadili orang karena alasan suku, jenis kelamin, agama, kewarganegaraan, atau pandangan politik;

Persetujuan pemberian Bantuan atas permintaan Bantuan tersebut akan merugikan kedaulatan, keamanan, kepentingan, dan hukum nasional;

Negara asing tidak dapat memberikan jaminan bahwa hal yang dimintakan Bantuan tidak digunakan untuk penanganan perkara yang dimintakan; atau

Negara asing tidak dapat memberikan jaminan pengembalian barang bukti yang diperoleh berdasarkan Bantuan apabila diminta.

Penolakan bantuan timbal balik dalam masalah pidana juga diatur dalam Pasal 7 Undang-Undang Republik Indonesia Nomor 1 Tahun 2006 Tentang Bantuan Timbal Balik yakni:

\section{Pasal 7}

Permintaan Bantuan dapat ditolak jika:

Permintaan Bantuan berkaitan dengan suatu penyidikan, penuntutan, dan pemeriksaan di sidang pengadilan atau pemidanaan terhadap orang atas tindak pidana yang jika dilakukan dalam wilayah Indonesia, bukan merupakan tindak pidana;
Permintaan Bantuan berkaitan dengan suatu penyidikan, penuntutan, dan pemeriksaan di sidang pengadilan atau pemidanaan terhadap orang atas tindak pidana yang jika dilakukan di luar wilayah Indonesia, bukan merupakan tindak pidana;

permintaan Bantuan berkaitan dengan suatu penyidikan, penuntutan, dan pemeriksaan di sidang pengadilan atau pemidanaan terhadap orang atas tindak pidana yang terhadap orang tersebut diancam dengan pidana mati; atau

Persetujuan pemberian Bantuan
atas permintaan Bantuan tersebut akan merugikan suatu penyidikan, penuntutan, dan pemeriksaan di sidang pengadilan di Indonesia, membahayakan keselamatan orang, atau membebani kekayaan negara.

Menteri yang bertanggung jawab di bidang hukum dan hak asasi manusia sebagai pejabat pemegang otoritas (Central Authority) yang berperan sebagai koordinator dalam pengajuan permintaan bantuan timbal balik dalam masalah pidana kepada negara asing maupun penanganan permintaan bantuan timbal balik dalam masalah pidana dari negara asing.

\section{PENUTUP}

Pembaruan hukum merupakan kebijakan yang dilakukan oleh suatu negara untuk menghadapi siatusi yang terjadi di negaranya. Berkembangnya kejahatan transnasional direspon oleh negara melalui kebijakan bantuan hukum timbal balik sebagaimana yang dituangkan dalam Undang-Undang Republik Indonesia Nomor 1 Tahun 2006 Tentang Bantuan Timbal Balik dalam Masalah Pidana. Kerjasama antara negara dalam proses penegakan hukum perl dilakukan untuk penanggulangan kejahatan peredaran gelap narkotika. Peredaran gelap narkotika dilakukan dengan melibatkan beberapa negara sebagaimana yang dinyatakan dalam United Nations Convention against Transnational Organized Crime. Menurut Konvensi ini, bantuan hukum 
timbal balik harus diberikan semaksimal mungkin berdasarkan undang-undang, perjanjian, perjanjian dan pengaturan yang relevan dari Negara Pihak yang diminta berkenaan dengan investigasi, penuntutan dan proses peradilan.. Bantuan hukum timbal balik dalam kejahatan narkotika dapat dilaksanakan melalui tiga cara, yaitu jalur diplomatik, melalui otoritas pusat dan melalui kerja sama antarlembaga penegakan hukum secara langsung.

\section{DAFTAR PUSTAKA}

Andi Eva Nurliani dan Dahlan Pasaribu, (2020), Bantuan Hukum Timbal Balik Dalam Masalah Pidana/Mutual Legal Assistance In Criminal Matters (Mla): Mekanisme Kerja Sama Penegakan." Badan Pengembangan Sumber Daya Manusia Hukum Dan Hak Asasi Manusia Kementerian Hukum Dan Hak Asasi Manusia Republik Indonesia, Jakarta.

Romli Atmasasmita (1997), Tindak Pidana Narkotika Transnasional dalam Sistem Hukum Pidana Indonesia, Citra Aditya Bakti, Bandung.

Siswanto Sunarso, (2009), Ekstradisi dan Bantuan Timbal balik dalam Masalah Pidana: Instrumen Penegakan Hukum Pidana Internasional, Rineka Cipta, Jakarta.

Soedarto, (1983), Hukum Pidana dan Perkembangan Masyarakat Kajian Terhadap Hukum Pidana, Sinar baru, Bandung.

Soedjono D. (1977), Segi HUkum tentang Narkotika di Indonesia, Karya Nusantara, Bandung.
Soerjono Soekanto, (1996), Sosiologi Suatu Pengantar, Rajawali Press, Jakarta.

Wijaya A.W. (1985), Masalah Kenakalan Remaja dan Penyalahgunaan Narkotika, Armico, Bandung.

Badan Narkotika Nasional, Lintas Batas Negara Entikong Jalur Favorit Penyelundupan Narkotika, https://bnn.go.id/lintasbatas-negara-entikong-jalurfavorit-penyelundupan-narkotika/

Darma, I. Made Wirya, Ni Nyoman Sri Wisudawati, and I. Gede Agus Kurniawan. "Mutual Legal Assistance (Mla) In The Resolution of Narcotics Crime As A Transational Organized Crime." Kertha Patrika 42.1 (2020): 5260.

Sarayar, Arga A. "Kajian Hukum Bantuan Kerjasama Timbal Balik (Mutual Legal Assistance) Dalam Penyelesaian Tindak Pidana Internasional." Lex Et Societatis 7.11 (2020).

Sitorus, R. J. (2016). Penggunaan Narkotika Mendukung PerilakuPerilaku Berisiko. Jurnal IImu Kesehatan Masyarakat, 7(1). 